\title{
Adult education in South African public libraries: a profile of activities
}

\author{
Mary Nassimbeni ', \\ Centre for Information Literacy, University of Cape Town \\ mnassimbeni@ched.uct.ac.za \\ and \\ Bev May², \\ Cape Town City Libraries, South Africa
}

Received: $13^{\text {th }}$ October 2005

Accepted: $30^{\text {th }}$ January 2006

\begin{abstract}
This paper reports on the findings of a research investigation into the role of South African public libraries in adult education ${ }^{3}$. A questionnaire was distributed to 1295 public libraries for the collection of statistical and qualitative information in an attempt to build national and provincial profiles of adult education activities. There was a good response rate of $45.5 \%$. The survey was complemented by site visits to eleven public libraries in order to illuminate the issues facing libraries in this field The results show that most public libraries do not participate at all in any adult education initiatives: $76.9 \%$ do not participate while $23.1 \%$ do. A profile of activities is presented. A case study of a single anonymous library is presented to provide an opportunity to understand the lived experience of the activities from the perspective of the providers and of the learners. The paper concludes by speculating on the reasons for the low level of engagement in an area that is theoretically espoused by the library community.
\end{abstract}

Keywords: Adult Literacy; Public Libraries; South Africa

\section{Introduction}

It is widely recognised that high rates of illiteracy levels have deleterious effects on economic and social advancement, particularly in developing countries. The eradication of illiteracy is one of the key goals of the global community reflected in such major policy initiatives as the declaration in 2001 by the General Assembly of the United Nations of the United Nations Literacy Decade for the period 2003-2012 (Today literacy remains a global challenge, n.d.). This was seen as an important link to the goal set in Dakar at the 2000 World Education Forum which aimed to achieve acceptable primary education for all children, and a reduction of adult illiteracy by $50 \%$. In 2000 there were 877 million illiterate adults in the world. Sub Saharan Africa has one of the highest rates of $37 \%$.

Proclaiming the Decade of Literacy in 200I, the United Nations stated that a literate environment is necessary to eliminate poverty, to achieve gender equality and to ensure sustainable development. The objectives of the Decade include:

- Reduction of the number of illiterate people especially women and those living in regions with high rates of illiteracy such as Africa and South Asia

- The creation of dynamic literate environments

- Improvement of the quality of lives of those who participate in literacy programmes (Literacy - the 877 million, 2002: 7).

This declaration puts the onus on governments to work with other agencies to achieve its goals. Among the agencies that have worked with governments and NGOs to address the problem is the public library whose core business is the promotion of reading. In South Africa, the contribution of pubic libraries to this cause has not been widely recognised, nor even very visible. While activities in the Western Cape are reasonably well documented, information about interventions in other provinces is sketchy and fragmented. A comprehensive South African adult education overview presented by Professor Shirley Walters of the University of the Western Cape was able to refer to only one paper giving an account of library-related activities.

The research project reported in this paper arose from the belief that there could be greater coordination and better use of resources if the involvement of public libraries in adult education were adequately documented. Accordingly it would be possible for libraries to establish effective partnerships for greater impact. It was proposed that an investigation

I. Mary Nassimbeni is an Associate Professor in the Centre for Information Literacy, University of Cape Town

2. Bev May is a librarian with Cape Town City Libraries

3. The title of the full report on which this paper is based is Adult education and literacy in South African pubic libraries: a national survey. 2005. An investigation conducted for the Print Industries Cluster Council Working Group on Libraries by Bev May and Mary Nassimbeni 
to survey, describe and analyse adult education activities in South African public libraries, would be of benefit to all public libraries as it would provide:

- An information resource

- A means of identifying areas in particular need

- A way of identifying common areas of difficulty

- Information about successful initiatives and lessons learned by colleagues in the field.

\section{Literature review}

A review of the literature of adult education with specific reference to the role of public libraries was very helpful to locate the study in the broader field to understand the political, economic and social dimensions of the problem.

\subsection{Adult education in South Africa}

Aitchison, a leading academic notes that there has been a trend since the 1990s to locate literacy in adult basic education and training (ABET) (Aitchison, n.d.). He defines adult basic education as "education provision for people aged fifteen and over who are not engaged in formal schooling or higher education and who have an education level less than grade 9 (Standard 7) (Aitchison, n.d.:2). The literacy/illiteracy statistics are difficult to pin down, as various sources present different figures. An examination of a couple of sources - official and expert - is sufficient to conclude that illiteracy is a significant problem in South Africa. In a speech in 200I, Professor Kader Asmal, Minister of Education at the time, noted that

... 3.5 million adults over the age of 16 have never attended school; another 2.5 million adults ... have lost their earlier ability to read or write. That makes essentially 6 million South Africans who are essentially barred from the written word, from the whole universe of information and imagination that books hold; and also from the more functional everyday empowerment that written languages gives - for employment for travel and to be a responsible citizen (Speech by the Minister of Education, Professor Kader Asmal ... 200 I).

In this statement and in many briefings, reports and policy documents, the government has committed itself to the reduction of illiteracy. It has adopted the Dakar Framework for Action whose fourth goal refers to the halving of illiteracy by 2015. In a report by the Department of Education in 2002 it is stated that "adult literacy is by far the most urgent development goal" of South Africa given their estimate that close to 7 million people who have not completed seven years of primary schooling will have to be reached" (South Africa. Department of Education, 2002: 48).

In the Confintea review for South Africa Walters sketches the contours of adult education provision pointing out that formal programmes are offered by a number of government departments, the private sector, and not for profit organisations. She estimates the contribution of the public benefit sector stretching from individual initiatives to large NGOs offering comprehensive services at about 10\% (Confintea mid-term review 2003).

\subsection{South African public libraries and adult education}

South African public libraries have long subscribed to the important educational role of public libraries as outlined in the IFLA/UNESCO Pubic Library Manifesto (1994), a most influential document in library development.

The public library, the local gateway to knowledge, provides a basic condition for lifelong learning, independent decision-making and cultural development of the individual and social groups. The Manifesto proclaims UNESCO's belief in the public library as a living force for education, culture and information, as an essential agent for the fostering of peace and spiritual welfare through the minds of men and women" (IFLA/UNESCO public library manifesto, 1994).

They have been very visible in providing space, resources and other facilities for school students who increasingly rely on the services of public libraries given the unsatisfactory state of school libraries. A number of commentators have observed that the public libraries' efforts to meet these needs have compromised the services of public libraries and that a solution needs to be sought (Hibbert, 1999; Epstein, 1998). The library is also a valuable resource for lifelong learning, especially for the "well educated, literate, middle class members of the community" as revealed in a survey by Mostert (1998: 72).

In a paper on ABET provision in South Africa Aitchison characterises public libraries as belonging to a group of agencies still enthusiastic about $A B E T$, finding that, in particular, the provincial library services have shown support through the provision of easy reading material (Aitchison n.d.: 17). It is worth noting that internal evidence suggests that he is referring to the situation in the first half of the 1990s. Harley notes that public libraries' involvement in adult education dates back in the main to the 1990s, particularly triggered by the International Year of Literacy in 1990 and in keeping with the political changes then in the offing (1999: 34). An examination of the published literature, and conference presentations shows that most of what is written and said about the public library's role in adult education refers to the realm of possibility rather than a record of achievement (Cf Davis 2004). Indeed, much of the professional literature laments the dearth of adult education activities in the public library, urging a new vision for the public library as 
an educational and development institution in South Africa, as elsewhere on the continent (Cf Cram, 2004). The survey of public libraries in Africa by Issak makes the point that although "the public library system in South Africa can be considered the most sophisticated on the continent ... [it is now] facing alarming deterioration" in part because of budget cuts (Issak, 2000: 7).

\section{Method and procedures}

Following an extensive literature review, a postal survey, complemented by case studies, was chosen as the most suitable research approach. The questionnaire sought statistical and also qualitative information in an effort to build national and provincial profiles of the literacy and adult education activities in public libraries. The questionnaire is attached as Appendix I. A number of sites were chosen for field visits in an effort to understand the lived experience of the activities, both from the providers' perspective, and also from the learners' perspective. They were chosen to allow a geographical spread, and also as likely exemplars of best practice. The selection was guided by the information supplied in the questionnaire returns.

Information about public libraries, their numbers, provincial distribution, their location, and their affiliation was acquired from the Paclisa Directory. By 5 May 2004, one thousand two hundred and ninety-five (I 295) questionnaires were distributed, using the provincial and metropolitan library structures. Five hundred and eighty-nine (589) questionnaires were returned, a sound return rate of $45.5 \%$. Frequent reminders and phone calls were made to encourage librarians to return the questionnaires. Telephone interviews were also made to supplement missing data, and for further explication where responses were ambiguous. Where respondents noted in their questionnaire that they had desperate need of help in sourcing suitable material for adult learners, the fieldwork researcher made contact for them with the New Readers Project (NRP), an NGO working in the field of production and distribution of ABET material. This assistance was gratefully received. Table I displays the provincial breakdown of questionnaire distribution and returns.

Table I Questionnaire returns

\begin{tabular}{llll}
\hline Province & No. distributed & No. returned & Percentage return \\
\hline E Cape (EC) & 157 & 47 & $29.9 \%$ \\
Free State (FS) & 136 & 55 & $40.4 \%$ \\
Gauteng (Gau) & 216 & 56 & $25.9 \%$ \\
KwaZulu Natal (KZN) & 207 & 79 & $38.2 \%$ \\
Limpopo (Lim) & 37 & 12 & $32.4 \%$ \\
Mpumalanga (Mpu) & 91 & 50 & $54.9 \%$ \\
North West (NW) & 87 & 26 & $29.9 \%$ \\
Northern Cape (NC) & 101 & 66 & $65.3 \%$ \\
Western Cape (WC) & 263 & 199 & $75.7 \%$ \\
\hline Total & $\mathbf{1 2 9 5}$ & $\mathbf{5 8 9}$ & $\mathbf{4 5 . 5 \%}$ \\
\hline
\end{tabular}

\section{Results}

Findings from the survey data are presented and analysed to construct a national profile of activities, and a case study of a single library is presented in order to bring to life some of the issues uncovered in the survey. The national profile is based on returns from 589 questionnaires, out of a total of I 295 questionnaires distributed. The case study reflects the situation in one of eleven libraries chosen for site visits. Three libraries from Gauteng were visited, and two each KwaZuluNatal, the Eastern Cape, Free State and Western Cape. Logistical and financial reasons did not allow fieldwork in the other provinces.

\subsection{National profile}

By far the majority of libraries in each of the provinces do not participate at all in literacy activities: close to $77 \%$ of all libraries do not participate, while just over $23 \%(23.1 \%)$ do participate. A ranking of provinces comparing the extent of their activity in adult education, involved shows that the North West has the greatest proportion of its libraries involved in literacy $(42.3 \%)$, followed by KZN (40.6\%), then Gauteng (33.9\%), followed by the Western Cape (31\%), then Free State with 25.5\%, and Eastern Cape with 19.1\%. Northern Cape and Mpumalanga have no significant activity at all $(9.1 \%$ and $6 \%$ respectively representing six and three libraries respectively). Limpopo reported no activity at all. Figure I presents by province actual numbers of libraries involved in literacy, compared with those not involved.

An aggregation of the figures gives the national total: 157 libraries are involved in adult education, while 432 libraries do not participate at all. It was found useful to differentiate between two types of participation: one in which libraries are 


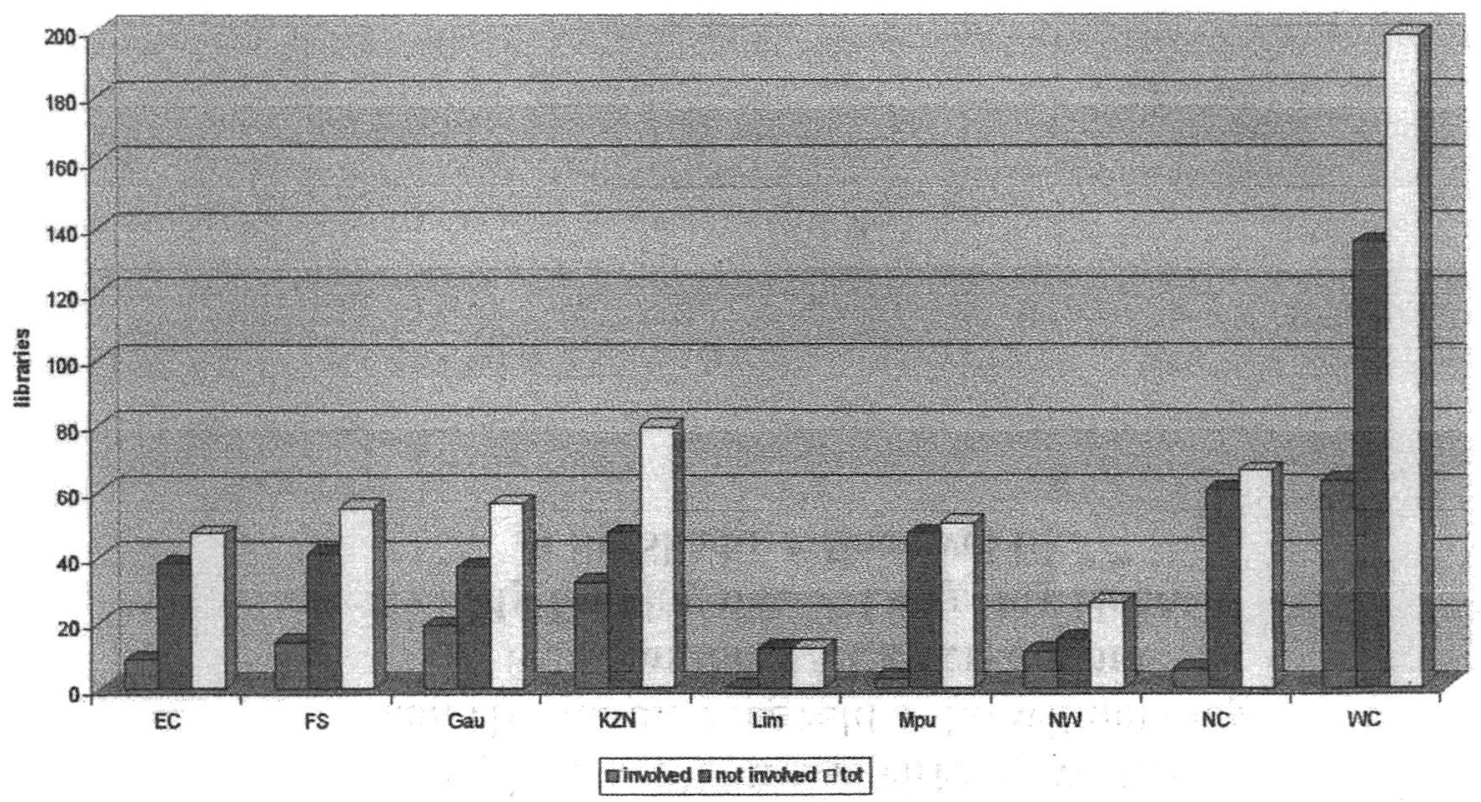

Figure 1 Libraries involved in adult education: numbers

actively engaged in the literacy programmes and activities, which tend to take place in the libraries (designated as direct involvement). The other type has been characterised as a supportive role in which the libraries do not host classes but offer support by way of a number of interventions, e.g. provision of a venue, making block loans to learners etc. Table 2 shows this breakdown in numbers.

Table 2 Profile of adult education involvement

\begin{tabular}{llll}
\hline Province & Direct involvement & Support role & No involvement \\
\hline E Cape & 0 & 9 & 38 \\
Free State & 2 & 12 & 41 \\
Gauteng & 13 & 6 & 37 \\
KZN & 13 & 19 & 47 \\
Mpumalanga & 1 & 2 & 47 \\
North West & 3 & 8 & 15 \\
Northern Cape & 6 & 0 & 60 \\
Western Cape & 25 & 38 & 135 \\
\hline Total & 63 & 94 & 432
\end{tabular}

The table shows that more libraries are involved in adult education in a supportive role, than as direct participants. The exceptions are in Gauteng and Northern Cape. Of the 157 libraries involved in adult education, 40.1\% are direct participants, while $59.9 \%$ have a support role. A number of libraries have built up valuable experience and expertise in the field. Twenty-seven libraries are relevant newcomers, with one year's experience. The greatest number (57) have between two and five years' experience, while 4I have between II and 20 years' experience. Twelve have been busy in the field for between six and ten years. One library in North West has been busy in the field for a most impressive 31 years. It is encouraging to note that libraries are still being attracted to the field in spite of the many barriers to entrance that are discussed in a later section. The overall picture of years of engagement shows commendable resilience as only sixteen libraries have a post with a portfolio designated for literacy work. Of these, one post is in the Free State, four in Gauteng, eight in KwaZulu Natal, one in Mpumalanga and two in the Western Cape. This is a very small cohort of literacy librarians drawn from the libraries with a direct role in literacy (63), or 157 of the total number of libraries participating in literacy activities. Accordingly one can conclude that the literacy work done in all the other libraries where there is no specific job or portfolio assigned by management to literacy, is done in addition to the formal job description. The low numbers of librarians with a specific responsibility for literacy calls into question issues of sustainability with respect to literacy activities. This issue is related to the question of funding which was also explored in the questionnaire. Staff salaries, of course, are but a single element in the resource needs of literacy programmes. One of the key barriers to participation in literacy was the issue of funding and finance and resources. 
With stable and guaranteed funding there is a reduction in stress and pressures on staffing resources. Erratic funding is a threat to stability and sustainability of literacy initiatives. Figure 2 ranks the funding agencies according to frequency. This shows how dependent the literacy programmes are on library funding in comparison to other sources of funding such as the Department of Education (DoE), local authority, business and the like. The library's contribution is admirable but difficult to sustain in a climate of financial stringency and budget cuts being experienced in the public library sector. The second most frequently mentioned source of funding is the learners' fees which is also problematic because the typical participant in a literacy programme is often a low wage earner or unemployed. Some of the respondents reported how difficult it is for many of the learners to find the money for transport to the library for their classes.

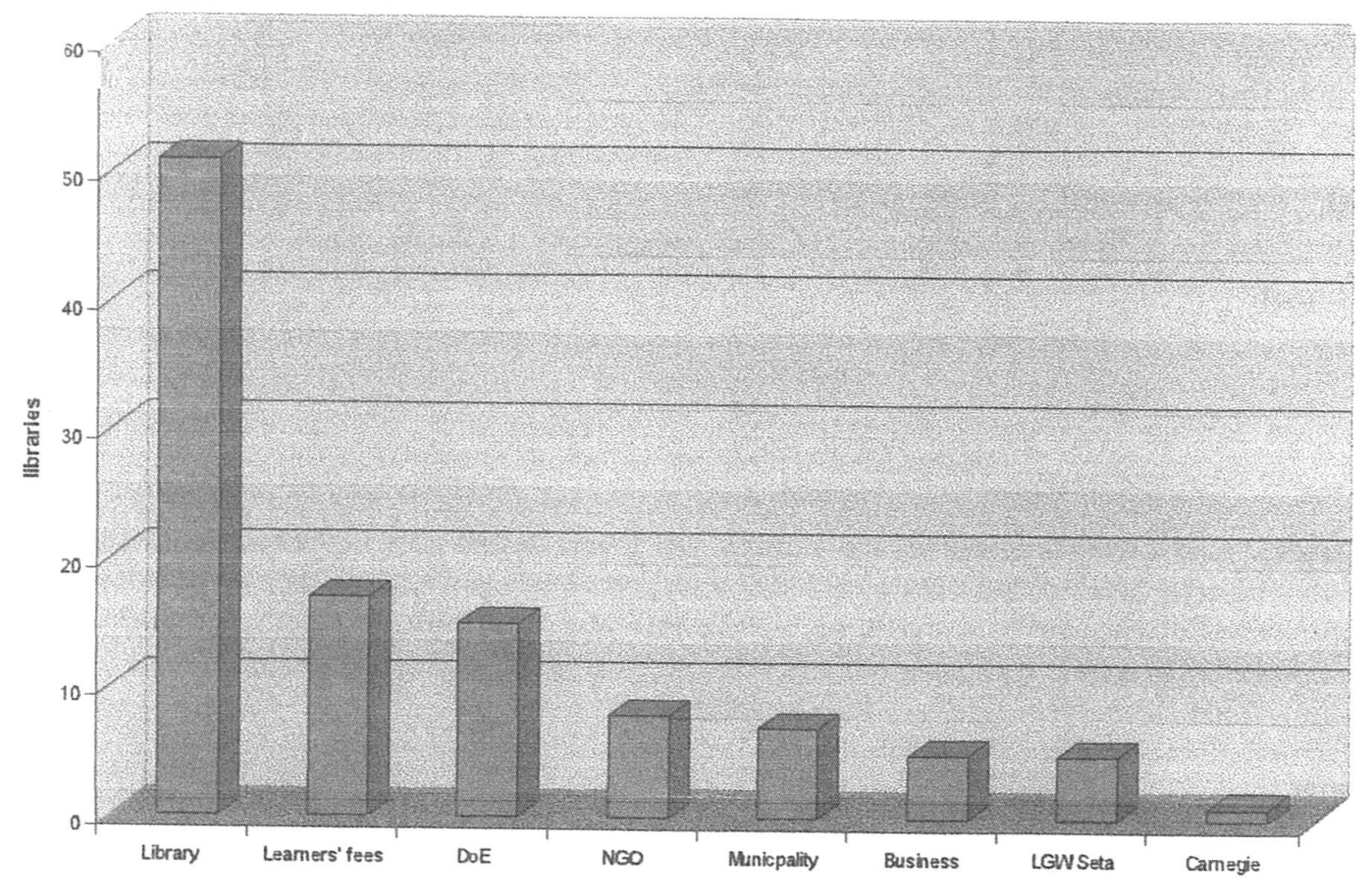

Figure 2 Sources of funding for literacy

Data related to the learning opportunities in the traditional areas offered in the programmes showed that the numbers of libraries offering English and numeracy exceed those offering mother tongue; the totals are 88 for mother tongue, 132 for English, and 104 for numeracy. All the librarians in the case studies reported a high demand for English classes and material among English second language speakers, and very little demand or interest in indigenous language material. The insistence on English can be linked to the employment and career advancement aspirations expressed to the fieldworker by the learners during the classes. Reports from the site visits explain this trend noting the great demand for English instruction, and relatively low interest in indigenous language materials.

Table 3 shows the sorts of adult basic education activities that are offered in addition to the typical literacy offerings, and the numbers of learners reached in these classes for the period 2001 to 2003. The figures are incomplete as a number of libraries did not supply numbers of learners as requested, but merely noted the fact that they offer classes in particular areas.

Table 3 Profile of adult education activities

\begin{tabular}{|c|c|c|c|c|c|c|c|}
\hline & Health & Income generation & Lifeskills & Literacy & Numeracy & Other & Total \\
\hline Free State & 27 & 27 & 75 & 64 & 60 & 93 & 346 \\
\hline Gauteng & & & 92 & 391 & 19 & & 502 \\
\hline $\mathrm{KZN}$ & 249 & 40 & 51 & 461 & 146 & 40 & 987 \\
\hline North West & & & 80 & 80 & 80 & & 240 \\
\hline W Cape & 65 & 19 & 212 & 453 & 298 & & 1047 \\
\hline Total & 341 & 86 & 510 & 1449 & 603 & 133 & 3122 \\
\hline
\end{tabular}

The questionnaire asked about external and internal examinations. Most libraries reported that their learners took examinations so as to acquire a formal qualification. Of the publicly available examinations written by the learners, most 
took the Independent Examination Board examinations, followed by the Department of Education, and then Unisa examinations. Table 4 presents the provincial pass rate of the learners ranked over the period 200I-2003, giving the number of learners who wrote, the number of learners who passed and the average pass rate.

Table 4 Learners' rate of success in the examinations, 200I-2003

\begin{tabular}{llll}
\hline & No. wrote & No. passed & \% pass rate \\
\hline Gauteng & 129 & 125 & $96.9 \%$ \\
KZN & 362 & 321 & $88.7 \%$ \\
Mpumalanga & 21 & 20 & $95.2 \%$ \\
N Cape & 141 & 136 & $96.5 \%$ \\
N West & 120 & 104 & $86.7 \%$ \\
W Cape & 625 & 411 & $65.8 \%$ \\
\hline Total & 1398 & 1117 & $79.9 \%$ \\
\hline
\end{tabular}

These results are very satisfactory with a pass rate of over $90 \%$ in three provinces, and over $80 \%$ in two provinces. Many respondents did not provide the figures as required, so that the numbers presented in this table are indicative, and not complete. Most of the teaching is done by paid facilitators (in 32 libraries), followed by volunteers ( 27 libraries) and then by library staff ( 19 libraries).

The study attempted to get an idea of the frequency and range of activities offered by the libraries acting in a supportive role to adult learners and their sponsoring organisations. The most frequently mentioned item is the provision of accommodation for the classes (63 libraries). The supply of library material through block loans to the literacy organisation is ranked equally with the arrangement of library visits ( 40 libraries). This is followed by the promotion of library membership, an important method of entrenching the reading habit and ensuring a stable supply of suitable reading material, a factor closely related to the retention of reading skills (25 libraries). Reading sessions are organised in eight libraries.

The libraries with direct participation in adult education programmes periodically offer a range of extramural activities to the learners. The most frequently offered is a visit to cultural institutions such as a museum, followed by visits to botanical gardens, and then to sites of natural beauty, such as Cape Point. Lifekskills expeditions such as visits to the fire fighting department and health clinics are also offered. Adult learners are also included in celebrations such as those marking literacy or reading events. These are all important enrichment activities offering enjoyment and learning opportunities to the participants. They are also important to motivate learners and for teambuilding.

Respondents were questioned about problems experienced in both categories of library. The most frequent complaints revolve around resource issues on the supply side: funding (36 libraries), lack of appropriate material (2I libraries), the lack of staff with appropriate training for literacy work ( 16 libraries) and lack of time ( 16 libraries). Only one problem is attributed to the learners, that of absenteeism, and this ranks equally with the problem of staff training and lack of time ( 16 libraries). A further resource constraint, lack of space, is mentioned by seven libraries, while four libraries cite inadequacy of literacy teachers and problems in recruitment. Problems of accreditation were mentioned by two libraries. Many of these problems could be solved if more resources were made available. The problem of absenteeism is a widely experienced phenomenon, often beyond the control of the literacy organisation/library. However, motivation remains an important factor in the retention of adult learners and should be borne in mind as an important educational requirement.

Those libraries with no involvement at all in literacy programmes were asked to indicate the reasons for this. Most of the reasons relate to internal resource constraints such as shortage of staff (139), no space (68), lack of funds (60), shortage of trained staff (59), shortage of material (40) and the like. Some (36) indicated that other organisations were responsible, and that therefore they saw no role for themselves. A total of 104 libraries ascribed their inactivity to external factors such as lack of interest, no need, opposition from the community, discouragement from the learners. If the factors relating to deficits reported by libraries are aggregated it can be seen that they outnumber the aggregated factors relating to the learners by four to one (409 as opposed to 104).

\subsection{Case study}

This case study of an anonymous but real library is presented as an example of a public library engaged in adult education activities, without significant external funding. It is one of a number of sites were chosen for field visits in an effort to understand the lived experience of the activities, both from the providers' perspective and also from the learners' perspective. The library selected is in a small town, located in a peri-urban area. 


\section{Bayton Public Library}

The library

The library is situated in a middle class, predominantly Afrikaans speaking, area of the town. It was not very busy on the day of the site visit. The adult easy readers (about 40 books) are on a shelf in front of desk. These Viva and Heinemann easy readers appeared to be well used.

The librarian

The library's involvement with literacy activity dates back to the time when the facilitator of adult education classes for the municipal staff was struggling with the English course and needing general information. The classes were held next door and the facilitator regularly asked to borrow dictionaries and project material. The relationship developed to the point where the facilitator regularly asked for assistance while planning the lessons and a good relationship developed. There is good teamwork in the municipality, and the library enjoys a good relationship with the community. The learners are given time off for their study, and the facilitators are very committed. The librarians demonstrate information technology and the fax machine to the learners. They try to meet the needs and demands of the facilitator and the class. They lend books to the learners through a block loan system which allows them a six-month loan period. There are between sixteen and thirty learners in the programme which is run after library working hours so that the librarians do not see as much of them as they would like. They have sufficient material except would like to have more easy Xhosa readers. They plan to invite the learners to celebrate Adult Learners' Week and Library Week in the library. The librarians do not find their participation labour intensive, and view the rewards when the adult learners join the library.

The librarians are anxious that the classes should continue - there has been a suggestion that they might be discontinued. They would like to be able to provide free Internet access to the learners, and also to have a project which links their ABET class via the Internet to other local ABET initiatives. If the library had the funds the librarian would like to start a reading project with the learners so that she could reward them. She would like to buy books for the learners which they can keep as she believes book ownership is important. The library has noted a few instances where the classes have impacted positively on the learners' lives and their employment prospects. One who was a messenger is now a switchboard operator. They have also noted marked improvement in their self-confidence. The librarian has not managed to source appropriate Xhosa fiction; what she has seen has tended to be poor translations. However, the learners prefer English material. Most of the Xhosa material is sent to a new satellite library which opened a year ago two kilometres away. The adult learners and facilitator complain that this library, their "home" library, is open only once a week.

The facilitators

The facilitators complained that there are not many books in mother tongue for Level I (Xhosa). More Level I Xhosa and English Easy Readers are needed. The library does not have enough computers: one computer for ten to fifteen learners is inadequate. They are also anxious as they have heard that the programme might be discontinued. They and the learners enjoy the ease of access to the library from the classes which are held next door. Some of the learners arrive early so as to use the library. The facilitators appreciate the role the library plays with the learners, finding that:

The librarians are helpful

The library is a most important resource for general ABET information

Learners use the library practically every week

They have been shown how to use a computer

They have been shown how to take out books

The learners have experienced an increase in their confidence

The facilitators enjoy a good relationship with the library, and the library has a good relationship with the learners. The librarians who are friendly and approachable help them find information and material and provide good reference sources for the facilitators. They support the programme by providing a professional reading service for learners.

The class

There were fifteen learners present during the visit; they were keen to share their experience of the classes as their observations show:

"These classes mean a lot to me - I started in Level 2 and am now in Level 4"

"It is an opportunity to go further - which I didn't know before"

"The community learn to respect each other"

"I am learning English"

"I learned a lot. I was in Level I and am now in Level 3"

"I am achieving my goal. I have progressed from Grade 2 to Grade 6" 
"I like to show my certificate to my children - I want very much to achieve and learn something better"

"It is helping me to speak and write English"

"I am able to help my children with schoolwork"

"I need that certificate - I want to follow a career in water treatment"

A tractor driver was promoted to metre reader and now wants to be a business manager

One learner wants to work in telecommunications - he wishes to be a supervisor for which he needs computer skills

One learner was a labourer, then a lawn mower operator, now he wishes top be an assistant supervisor

A plumber's assistant is now a plumber

They expressed gratitude to the librarians whom they find friendly and helpful. One praised the library: "The library is everybody's Morningstar - Ikwesi Lokusa". They are pleased that the library is so close to their classroom. They would appreciate more computers, access to the Internet, and being able to have regular and convenient access to their home library two kilometres away.

Lessons learned

The librarian, commenting on the library's role in adult education, emphasised the importance of building partnerships and relationships in order to provide the service to the adult learners. It took the library five years to build up the relationship. She would advise other libraries to be proactive and invite adult education facilitators in to see what the library can do

\section{Conclusion}

The library seems well rooted in the community. There is a good relationship between the library and the municipality. The librarians understand the importance of building partnerships, and appreciate that community work and relationships take a long time to build. There is a very strong and committed adult learner group - all seem to have progressed from labourers to more skilled jobs and are hoping for supervisory positions soon.

\section{Discussion of findings and conclusions}

Although the survey of adult education in public libraries in 1994/1995 by Harley (1999: 29) expressed the view that it is imperative for libraries to engage in adult education, the current investigation has found that support of literacy and adult education is not wide spread in South African public libraries. Only $23.1 \%$ of public libraries participate directly or in a support role in adult education, while the overwhelming majority (76.9\%) are not involved. Thirty-six of the 432 nonparticipating respondents would like to participate in the future, i.e. $8.3 \%$. Among the participating libraries, the interventions range from rather passive inputs such as making a venue available, to energetic and active involvement including teaching literacy classes and providing lifeskills courses. A good number of the libraries (30\%) have been involved in literacy from between eleven and twenty years while the category of between two and five years attracted the most responses (4I.6\%). Almost $20 \%$ are very recent entrants (one year) while nearly $9 \%$ have been involved between six to ten years.

The most compelling question to emerge from the investigation is: "Why are so few public libraries in South Africa involved in adult education?" This finding is at odds with the transformative agenda of the public library community of South Africa. For example, the theme of the 2005 annual conference of the Library and Information Association of South Africa (LIASA) was "Taking Libraries to the People". The theme for the South African Library Week for 2006 is "Libraries: partners in learning, nation building and development". A very significant opportunity to work with partners in this important national agenda is through adult education which is widely recognised as an important development activity contributing to the alleviation of poverty (Rule, 2005).

A couple of possible reasons for the inactivity suggest themselves. Adult education is an area totally outside the mission of the public library system in South Africa and therefore irrelevant. Alternatively, although adult education forms part of the portfolio of services to be offered by public libraries, it is viewed as less important than the others, and therefore gets displaced by more urgent demands. The problems experienced by the libraries involved, and the reasons put forward by non-participating respondents overwhelmingly suggest that serious resource problems impede efforts or are barriers to entering the field. The financing of public libraries has been identified as a serious matter for concern by numerous commentators and stakeholders. In a recent press release Elisabeth Anderson, a member of the National Council for Library and Information Services, reported that the government was being asked to intervene in the critical situation faced by pubic libraries which are suffering budget cuts leading to cuts in staff and opening hours "and even the closure of libraries" (Financial woes of libraries, 2005). This has been linked to (and perhaps exacerbated by anomalies of governance), which is a constitutional issue (Budlender, 2005). Budlender's investigation showed that:

SA JnI Libs \& Info Sci 2006, 72(I) 
The constitutional issue as to which sphere of government bears responsibility for funding and, if it is shared, which sphere bears responsibility for which aspects, is clearly a significant factor in the current funding problems faced by libraries (2005: 86).

Our view is that that the public library has a rightful role in development and a moral imperative to join the struggle against poverty through engagement with adult education. There is already a reasonably firm foundation on which the adult education agenda can be built. This will require commitment by the public library community with respect to policy direction, planning, and consequent resource allocation. A notable area requiring urgent attention is the lack of suitable training opportunities which emerged as a very prominent feature in the survey data. Unless training for librarians includes a specific component on adult education, there is very little chance that any initiatives are likely to be successful. This finding is consistent with research conducted elsewhere which has pointed to the general problems around the education and training of public librarians (Hart, 2005).

The investigation has shown that there are a number of libraries, in the category of direct participation, with imaginative and energetic approaches to adult education in their communities. The libraries acting in a supportive role are also making a valuable contribution and could be encouraged to extend their interventions. The libraries that contribute to the fight against illiteracy by participating in adult education are to be commended for working in a field that has been experiencing setbacks, disappointments and slow progress in the first decade of democracy.

\section{References}

Aitchison, J. n.d. A review of adult basic education and training in South Africa. Paper available at $h t t p: / / w w w . a d e a n e t . o r g / w g n f e /$ publications/nfe-systems/aitchison.pdf [2006, January 25] Budlender, D. 2005.The funding and governance of public libraries in South Africa. An unpublished report to the Print Industries
Cluster Council.

Confintea mid-term review: South Africa. 2003. Cape Town: Division for Lifelong Learning, University of the Western Cape. Available at: $h t t p: / / w w w . u n e s c o . o r g / e d u c a t i o n / u i e / p d f / c o u n t r y / R S A . p d f$ [2006, January 25]

Cram, J. 2004. Colonialism and libraries in Third World Africa. Australian library journal, 42 (I): I-9. Available at http:// www.alia.org.au/ jcram/african_libraries.html [2006, January 25]

Davis, G. 2004. Public libraries and a decade of democracy: rebirth or rethink? Paper delivered at the Liasa Annual Conference, Polokwane. Available at: $h$ ttp://www.liasa.org.za/conferences/conference2004/papers/LIASA_Conference_2004_Davis.pdf [2006,
January 25]

Epstein, R. 1998. Public libraries and schools. Cape librarian, 42(3): I4-15

Financial woes for libraries. 2005. Report on News24.com. Available at http://www.news24.com/News24/South_Africa/News/ 0,6/19,2-7-1442_17405/8,00.html [2006, January 25]

Harley, A. 1999. The role of public libraries in adult basic education in South Africa. Mousaion, 17 (1): 28-47 Hart, G. 2005. The readiness of public libraries in South Africa for information literacy education: the case of Mpumalanga
Province. Unpublished Ph D thesis. Cape Town: University of Cape Town

Hibbert, L. 1999. The future: learning @ the library. Paper presented at the 1999 annual LIASA Conference. Paper available at http://home.imaginet.co.za/liasa/papers/hibbert.html [2006, January 27] Issak, A. 2000. Public libraries in Africa: a report and annotated bibliography. Oxford: International Network for the Availability of
Scientific Publications Literacy - the 877 million. 2002. Education today, p. 4-8. Available at http://www.unesco.org/education/education_today/
today02.pdf [2006, January 25]

Mostert, B. J. 1998. Community libraries: the concept and its application - with particular reference to a South African community library system. International information and library review, 30(I): 7I-85

Rule, P. 2005. "The time is burning": the right of adults to basic education in South Africa. Forthcoming in Journal of education, Available at http://www.erp.org.za/htm/abet.doc [2006, January 25] South Africa. Department of Education. 2002. Education for all status report: South Africa, incorporating country plans for 2002 to
2015. Pretoria: Department of Education

Speech by the Minister of Education, Professor Kader Asmal, MP at the Readathon Launch organised by READ Education Trust, Johannesburg, 2 August 200I. 200I. Available at $h t t p: / / w w w . i n f o . g o v . z a / s p e e c h e s / 2001 / 010806945 a / 006 . h t m$ [2006, January 25]

Today literacy remains a global challenge, n.d. Available at: $h t t p: / / p o r t a l . u n e s c o . o r g / e d u c a t i o n / e n / e v . p h p-U R L \_I D=5000 \& U R L$ $D O=D O \_$TOPIC\&URL_SECTION $=201 . \mathrm{html}[2006$, January 25]

Unesco public library manifesto. 1994. Paris: Unesco. Available at: http://www.ifla.org/VII/s8/unesco/eng.htm [2006, January 30]

\section{Acknowledgements}

Funding for the project was received from the Department of Arts and Culture through the Print Industries Cluster Council, Other sponsors were Charlotte Roberts Trust, Adult Learning Network, Hargraves Library Service, Wordsworth Books, and an anonymous librarian. Cape Town Administration: City Libraries supplied photocopying, fax, e-mail and telephone facilities. The support of all is gratefully acknowledged. 


\section{Appendix I}

\section{QUESTIONNAIRE}

\section{SURVEY OF LITERACY ACTIVITIES AND ADULT EDUCATION IN PUBLIC LIBRARIES IN SOUTH AFRICA}

I would appreciate your participation in this research project by completing the questionnaire regarding adult basic education in South African public libraries.

This survey aims to describe and analyse literacy projects and related activities in South African public libraries.

\section{CONTACT DETAILS:}

NAME OF LIBRARY:

ADDRESS:

CONTACT PERSON \& POSITION

TELEPHONE NO.:

FAX NO.:

E-MAIL ADDRESS:

Please complete and return this form by 2004 and send to the following address:

Bev May - Cape Town Administration Libraries

PO Box 4728

CAPE TOWN

8000

Tel: (02I) 467-1542 Fax: (02I) 46I-598I

E-mail: Kathleen.Lawrence@capetown.gov.za

Please mark with a $\sqrt{ }$ the answer that represents your response.

\begin{tabular}{|l|l|}
\hline I Is your library currently involved in literacy and/or adult basic education \\
activities.
\end{tabular}




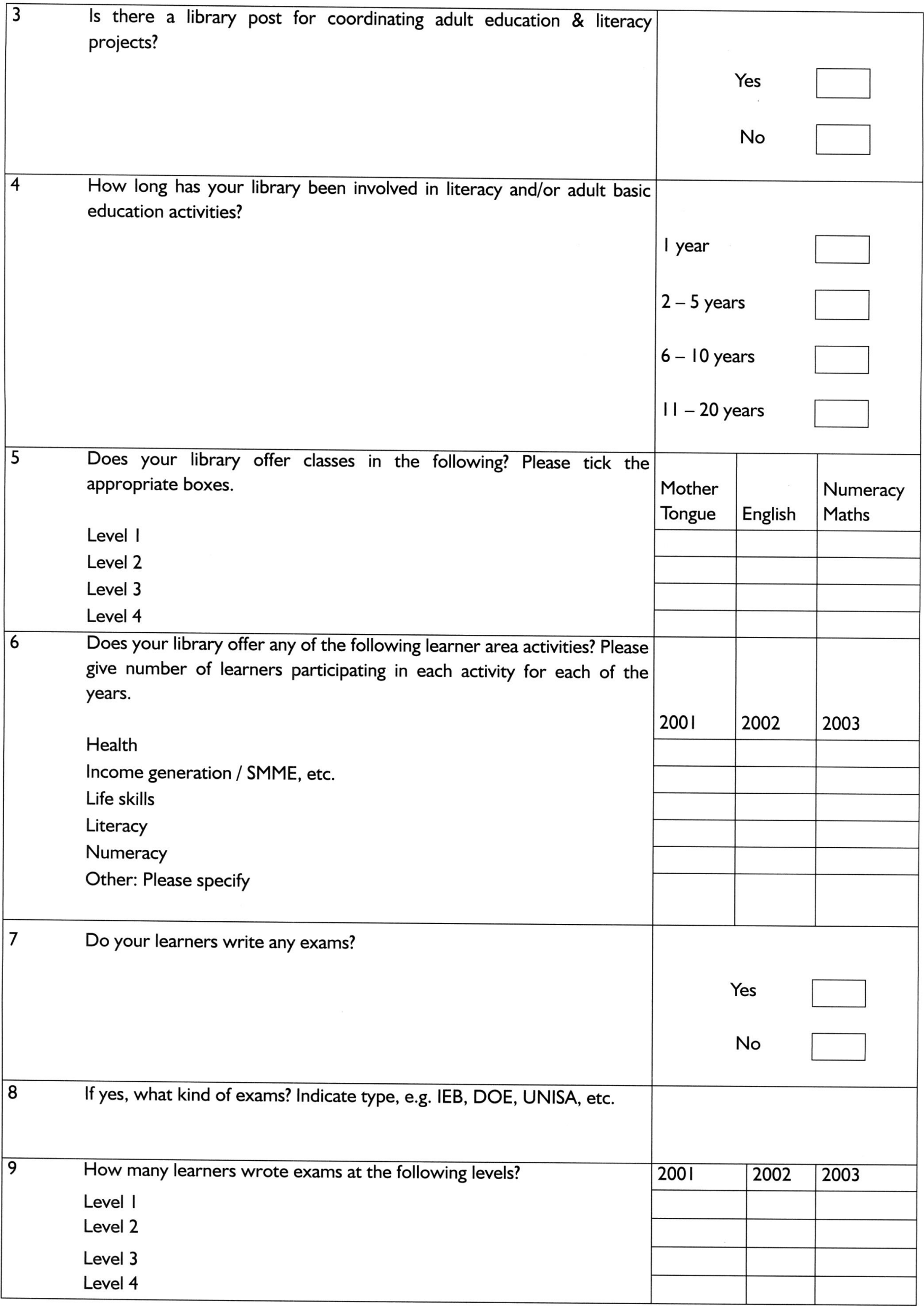




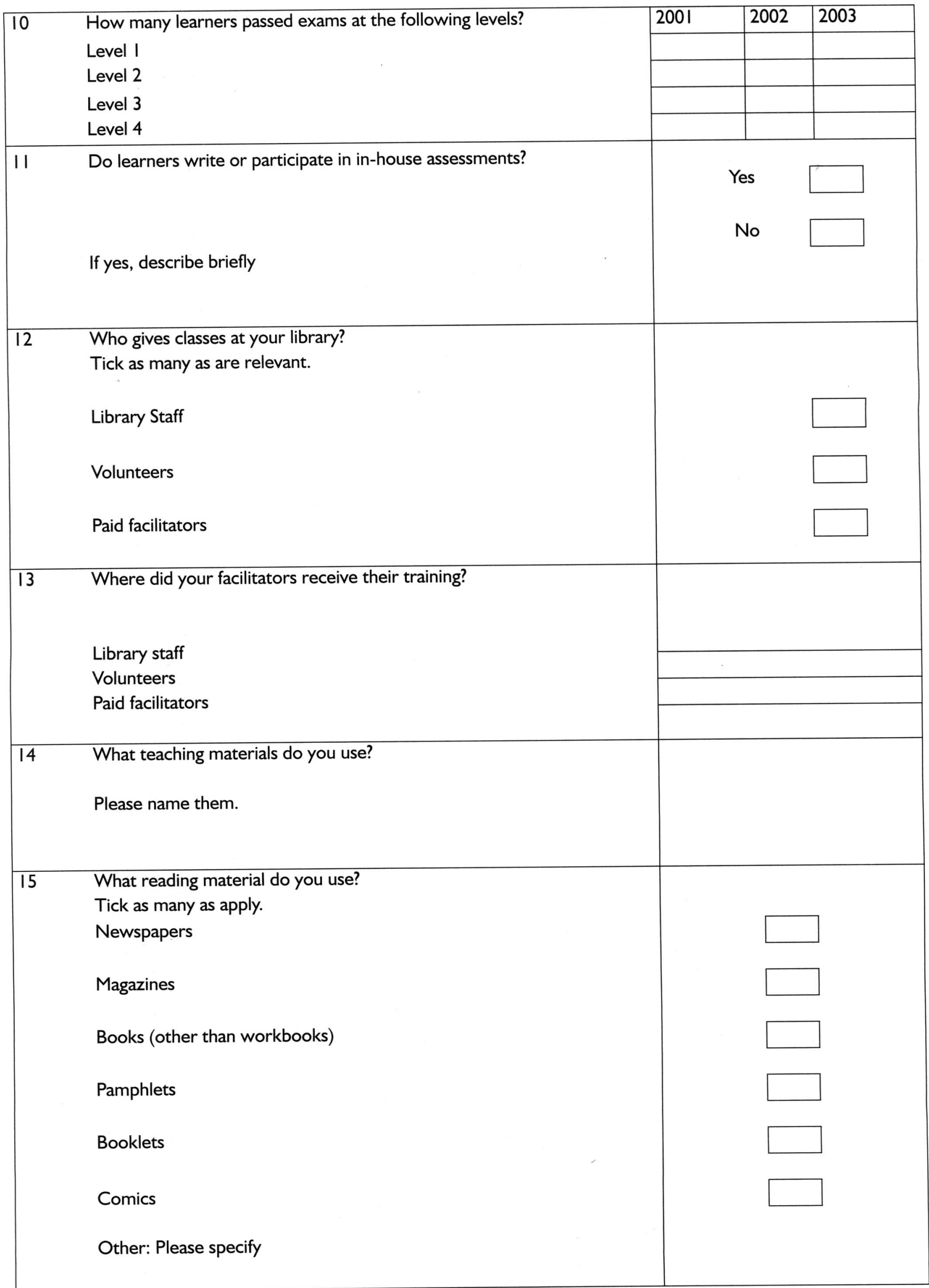




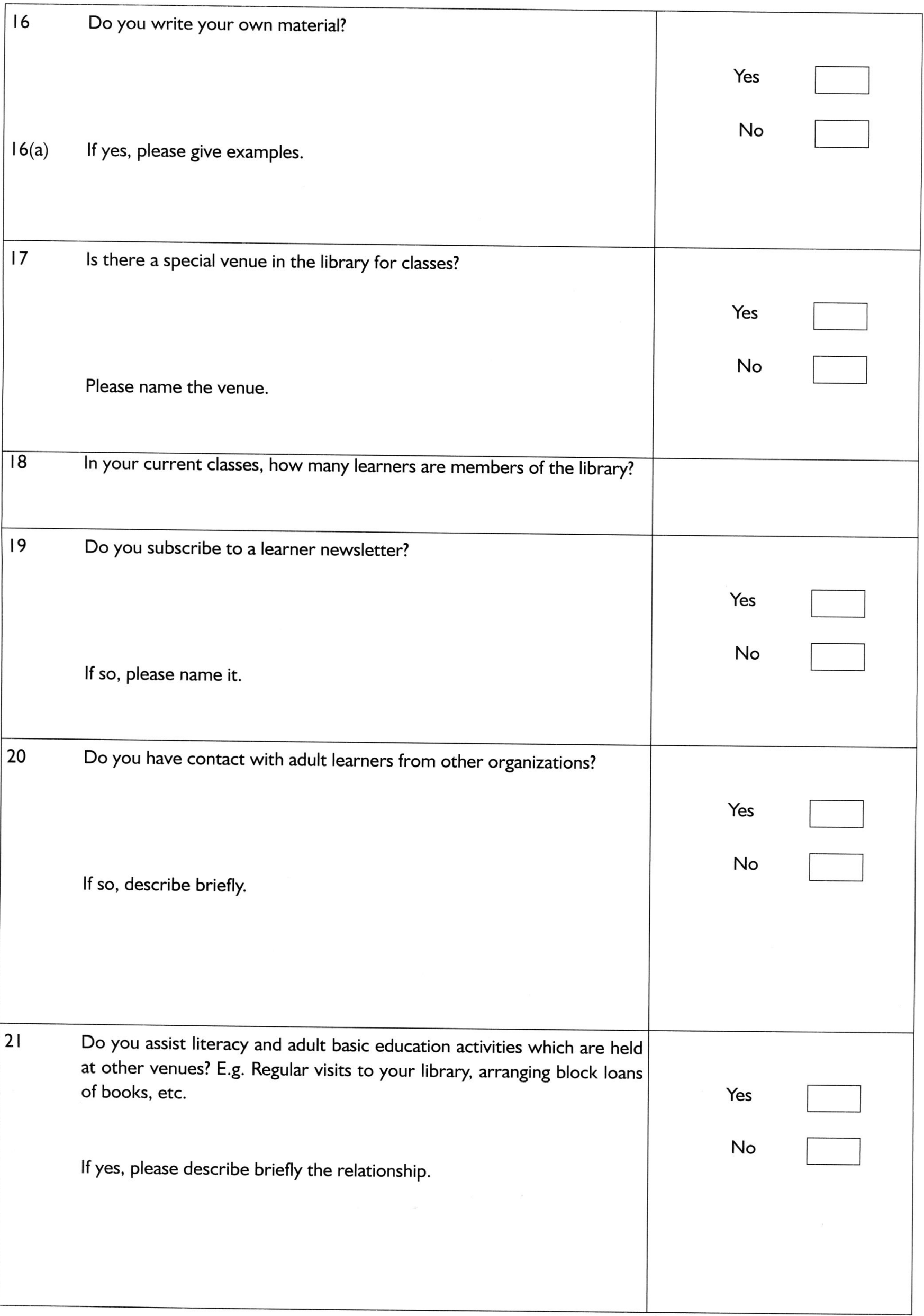


22 Do you involve your learners in activities outside the library? Visits to:

Museums

Movies

Botanical gardens

Other: Please specify

23 What partnerships, associations, organizations \& individuals assist you with your initiatives?

Please name them.

24 Do you know of any other organizations linked to adult basic education and literacy?

Please name them.

25 Would you like partnerships with such organizations?

Yes

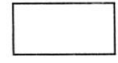

No

26 What are your sources of funding?

Department of Education

Library

Learner fees

Other: Please specify

27 What additional activities would you like to offer your learners, given additional funding?

Please name them. 
$28 \quad$ Please describe any problems you experience or have experienced in your adult education and literacy projects and activities.

29 If your library is not engaged in / or has stopped literacy / adult education initiatives - please explain why, problems experienced, etc.

30 Describe any particularly successful literacy/adult education initiatives in your library.

3I Please feel free to attach additional information about any of the above questions.

THANK YOU FOR FILLING IN THIS QUESTIONNAIRE.

I HOPE TO VISIT A NUMBER OF RESPONDING LIBRARIES.

Would you be willing for me to visit your library?

Yes

No 